\title{
Characteristics of Fluid Inclusion and D-O-S-Pb Isotopes Geochemistry of Jiaojia Gold Deposit
}

\author{
Yangyang Chen ${ }^{1} \&$ Bing Chen ${ }^{2}$ \\ ${ }^{1}$ The School of Earth Science and Resources, Chang'an University, China \\ ${ }^{2}$ Fourth Geological Exploration Institute of Heilongjiang Province, Harbin, China \\ Correspondence: Yangyang Chen, The School of Earth Science and Resources, Chang'an University, Xi'an, \\ 710054, China. E-mail: yangyang52c@163.com
}

Received: June 20, 2016

doi:10.5539/esr.v5n2p188
Accepted: July 5, 2016

Online Published: July 28, 2016

URL: http://dx.doi.org/10.5539/esr.v5n2p188

\begin{abstract}
The Jiaojia gold deposit is located in the northwest jiaodong ore-concentrated area, north wing of Laizhou-Xixia anticlinoria, the orebody occurred in the granite which exists the footwall of Jiaojia Fault, Jiaojia Fault is the eastern secondary NE-NNE trending fault of Tan-Lu Great Fault. There are three types of fluid inclusion in Jiaojia gold deposit, respectively are $\mathrm{H}_{2} \mathrm{O}-\mathrm{CO}_{2}$ inclusion ( $\mathrm{H}-\mathrm{C}$ type), $\mathrm{CO}_{2}-\mathrm{H}_{2} \mathrm{O}-\mathrm{CH}_{4}$ inclusion $\left(\mathrm{CH}_{4}\right.$-bearing type) and $\mathrm{H}_{2} \mathrm{O}$ inclusion ( $\mathrm{H}$ type). In Jiaojia gold deposit, the main ore-forming temperature is $170.2 \sim 358.1^{\circ} \mathrm{C}$, the salinity is ranging from $2.04 \mathrm{wt} \% \mathrm{NaCl}$.eq to $10 \mathrm{wt} \% \mathrm{NaCl}$.eq with a average of $6.64 \mathrm{wt} \% \mathrm{NaCl}$.eq, sum intensity is $(0.89 \sim 0.946) \mathrm{g} / \mathrm{cm}^{3}$, pressure estimation is $2 \times 10^{3} \sim 3.8 \times 10^{3} \mathrm{kPa}$, the Jiaojia gold deposit is mesothermal gold deposit. The metallogenic substances derived from a mantle-crust-mixed source according to the $\mathrm{S}$ and $\mathrm{Pb}$ isotopes. The Jiaojia gold deposit was formed in the late stage which was a tensional environment. The ore-forming fluids mainly derived from magmatic and meteoric water, and a fraction of metamorphic water. The Jiaojia gold deposit is formed in the Yanshanian.
\end{abstract}

Keywords: Jiaojia gold deposit, fluid inclusion, isotope

\section{Introduction}

Jiaodong is one of the most important gold producing area in China, it reserves account for $1 / 3$ of rock gold in our country has proven, its importance is self-evident.The Jiaojia gold deposit is located in the northwest Jiaodong ore-concentrated area, north wing of Laizhou-Xixia anticlinoria, the orebody occurred in the granite which exists the footwall of Jiaojia Fault, Jiaojia Fault is the eastern secondary NE-NNE trending fault of Tan-Lu Great Fault. Jiaojia gold deposit is one of the last three decades an important prospecting achievements for our broken with altered rock type gold, and achieved fruitful results of the prospecting, research results can be described as "voluminous".

Shandong Jiaojia gold deposit is the typical area for "Jiaojia Type" of broken belt altered rock type gold deposit, is also one of the important ore deposits in the geology study. However, the previous research of Jiaojia gold deposit is relatively inadequate and especially lack of systematic comprehensive geochemistry study such as fluid inclusion, stable isotopes, etc. therefore, it's important for us to study the geology characteristics, fluid inclusion and stable isotopes in this area, in order to conclude ore-forming regulations and metallogenic prediction in this region.

\section{Deposit Geology}

Jiaojia Gold deposit is located in the northwest of Jiaobei uplift, the north wing of Laizhou-Qixia anticlinorium, the secondary fault on the east of Yishu fault, occurred in the granite which formed in the footwall of Jiaojia main fault zone. The exposure strata in the regional context is dominated by the Archaean Jiaodong Group and also has the distribution of Proterozoic Fenzishan Group, Jingshan Group, upper proterozoic Penglai Group, mesozoic Group upper Jurassic and cretaceous system in local area, and the quaternary sediments is widely distributed (Fig. 1). 


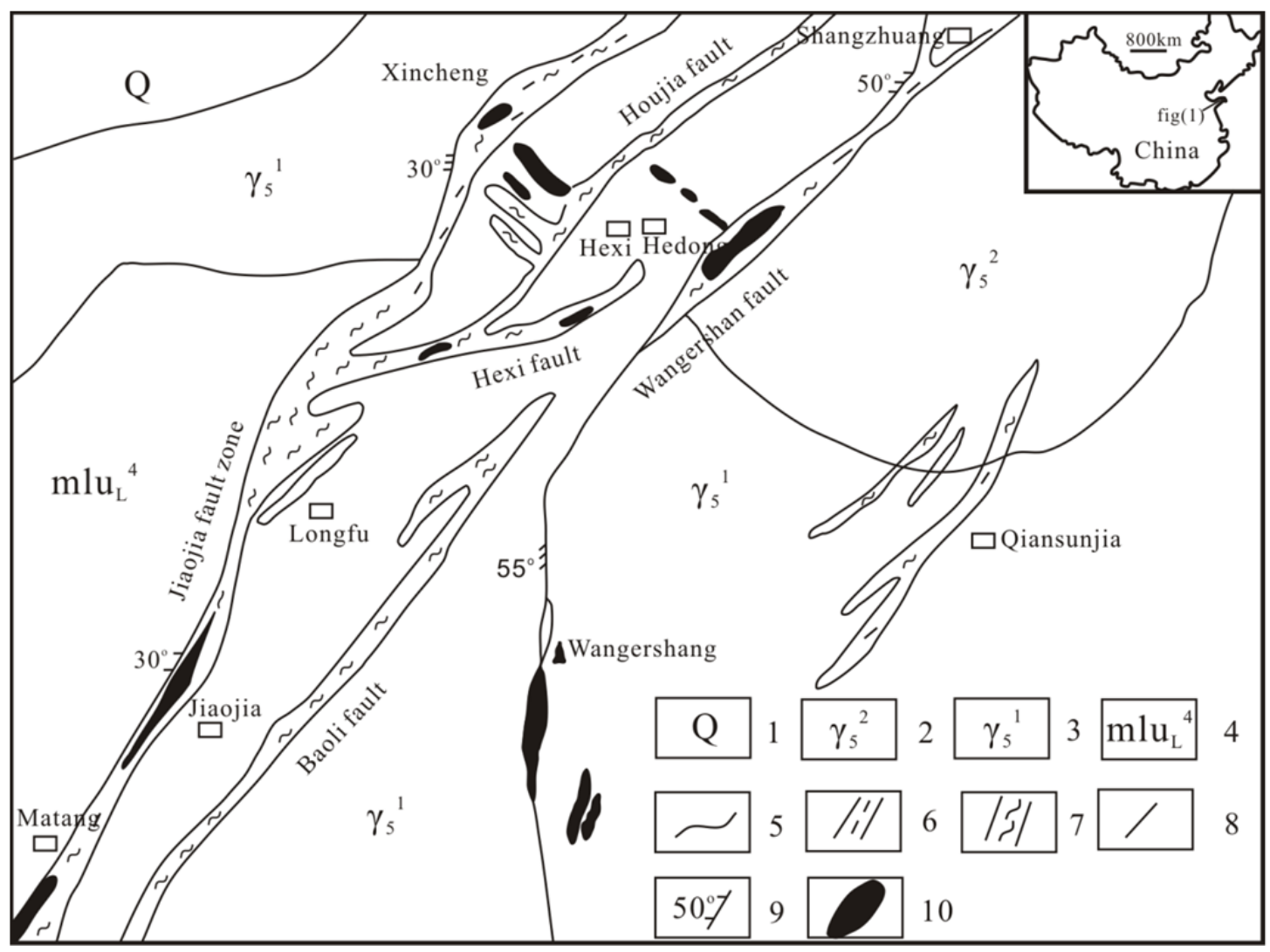

Figure 1. Geological map of Jiaojia gold deposit (modified after Li et al., 2002)

Note. 1. Quaternary; 2. Granodiorite of Guojialing; 3. Biotite granite of Linglong; 4. Metagabbro super unit of Malianzhuang (Amphibolite) ; 5. Geological boundary; 6. Early ore-controlling fracture alteration zone; 7. Middle mineralization alteration zone; 8. Fracture after mineralization; 9.The fracture and occurrence; 10.Gold orebodies.

The Jiaojia gold deposit is located in the middle section of Jiaojia Fault Belt where quaternary strata are extensively distributed. Bordered by main fracture, to the east is the Linglong monzonitic granite and Guojialing porphyritic granodiorite, to the west is the Malianzhuang metagabbro. The strata in the deposit area are simple, chiefly exposing Jiaodong Group of Archean Eonothem and thick Quaternary river alluvium, and major ore-controlling structure therein is Jiaojia fault. Demarcated by principal section, its eastern area is dominated by Linglong granite and western area is controlled by Jiaodong Group metamorphic strata. Jiaojia gold deposit occurs in the cataclastic alteration zone of Jiaojia principal section footwall. Besides, large-scale faults in this deposit area also include Hedong-Wang'ershan fault, Sizhuang branch fault, Houjia fault, Baoli fault, etc. Exposed plutons here are Linglong gneissic biotite granite and Guojialing granodiorite. $80 \%$ of the whole area is dominated by magmatite, the dykes are well-developed as well (Fig. 1).

\section{Stable Isotopes Geochemistry}

\subsection{Petrographic Characteristics of Fluid Inclusion}

The type of fluid inclusion of Jiaojia Gold Mine mainly includes the $\mathrm{H}_{2} \mathrm{O}-\mathrm{CO}_{2}$ inclusion ( $\mathrm{H}-\mathrm{C}$ type), $\mathrm{CO}_{2}-\mathrm{H}_{2} \mathrm{O}-\mathrm{CH}_{4}$ inclusion (including $\mathrm{CH}_{4}$ type) and $\mathrm{H}_{2} \mathrm{O}$ solution inclusion ( $\mathrm{H}$ type) under the microscope. The $\mathrm{H}-\mathrm{C}$ type is the main inclusion type, it presents 2 to 3 phases $\left(\mathrm{H}_{2} \mathrm{O}\right.$ liquid phase $\mathrm{L}_{\mathrm{H} 2 \mathrm{O}^{+}}+\mathrm{CO}_{2}$ gas phase $\mathrm{V}_{\mathrm{CO} 2}$ and $\mathrm{H}_{2} \mathrm{O}$ liquid phase $\mathrm{L}_{\mathrm{H} 2 \mathrm{O}}+\mathrm{CO}_{2}$ liquid phase $\mathrm{L}_{\mathrm{CO} 2}-\mathrm{CO}_{2}$ gas phase $\mathrm{V}_{\mathrm{CO} 2}$ ) under the room temperature; and 2-phase is more common. The inclusion $\mathrm{V}_{\mathrm{CO} 2}+\mathrm{L}_{\mathrm{CO} 2}$ generally takes up $30 \%-56 \%$ in volume of the inclusion; its size is

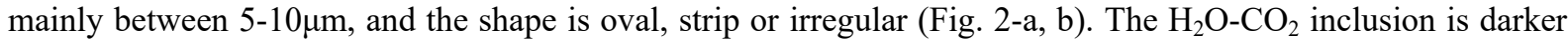
integrally, the boundary between the gas phase and liquid phase is blacker and thicker; the $\mathrm{L}_{\mathrm{CO} 2}\left(\mathrm{CO}_{2}\right.$ liquid phase) is in matt dark color, and only the center has lighter points. At the early metallogenic stage, the $\mathrm{H}_{2} \mathrm{O}-\mathrm{CO}_{2}$ inclusion is generated from tiny protogenetic inclusion; and it is the isolated or random distributed protogenetic inclusion at the main metallogenic stage. The inclusion (including $\mathrm{CH}_{4}$ ) is mainly concentrated in the main 
metallogenic epoch; the quantity is not so much; it coexists with the $\mathrm{H}-\mathrm{C}$ type inclusion, and the composition is $\mathrm{CO}_{2}-\mathrm{H}_{2} \mathrm{O}\left( \pm \mathrm{CH}_{4}\right)$. The $\mathrm{CO}_{2}-\mathrm{H}_{2} \mathrm{O}\left( \pm \mathrm{CH}_{4}\right)$ inclusion presents 2 to 3 phases $\left(\mathrm{H}_{2} \mathrm{O}\right.$ liquid phase $\mathrm{L}_{\mathrm{H} 2 \mathrm{O}}+\mathrm{CO}_{2}$ liquid phase $\mathrm{L}_{\mathrm{CO} 2}-\mathrm{CO}_{2}$ gas phase $\left.\mathrm{V}_{\mathrm{CO} 2}-\mathrm{CH}_{4}\right)$ under the room temperature, wherein $\mathrm{V}_{\mathrm{CO} 2}+\mathrm{L}_{\mathrm{CO} 2}$ generally takes up

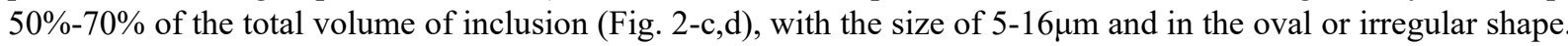
Most of inclusions are in matt dark color, and the boundary between gas phase and liquid phase is thick and black. This inclusion is rare at the early metallogenic stage, the main metallogenic epoch is represented as the random distributed protogenetic inclusion or distributed in the inclusion group, the random distributed protogenetic inclusion has larger gas liquid ratio change, and it often coexists with the $\mathrm{H}_{2} \mathrm{O}$ solution inclusion. There is no obvious petrographic difference between the $\mathrm{CO}_{2}-\mathrm{H}_{2} \mathrm{O}\left( \pm \mathrm{CH}_{4}\right)$ inclusion and the $\mathrm{H}_{2} \mathrm{O}-\mathrm{CO}_{2}$ inclusion under the microscope. According to the temperature measurement result, the complete melting temperature of solid $\mathrm{CO}_{2}$ is lower than the pure $\mathrm{CO}_{2}$ three-phase point $\left(-56.6^{\circ} \mathrm{C}\right)$, but the existence of $\mathrm{CH}_{4}$ may reduce $\mathrm{T}_{\mathrm{m}, \mathrm{CO} 2}$ of inclusion, so it can be presumed that the $\mathrm{CO}_{2}-\mathrm{H}_{2} \mathrm{O}\left({ }^{2} \mathrm{CH}_{4}\right)$ inclusion may appear in three phases. Such inclusion hardly exists at the late metallogenic epoch.
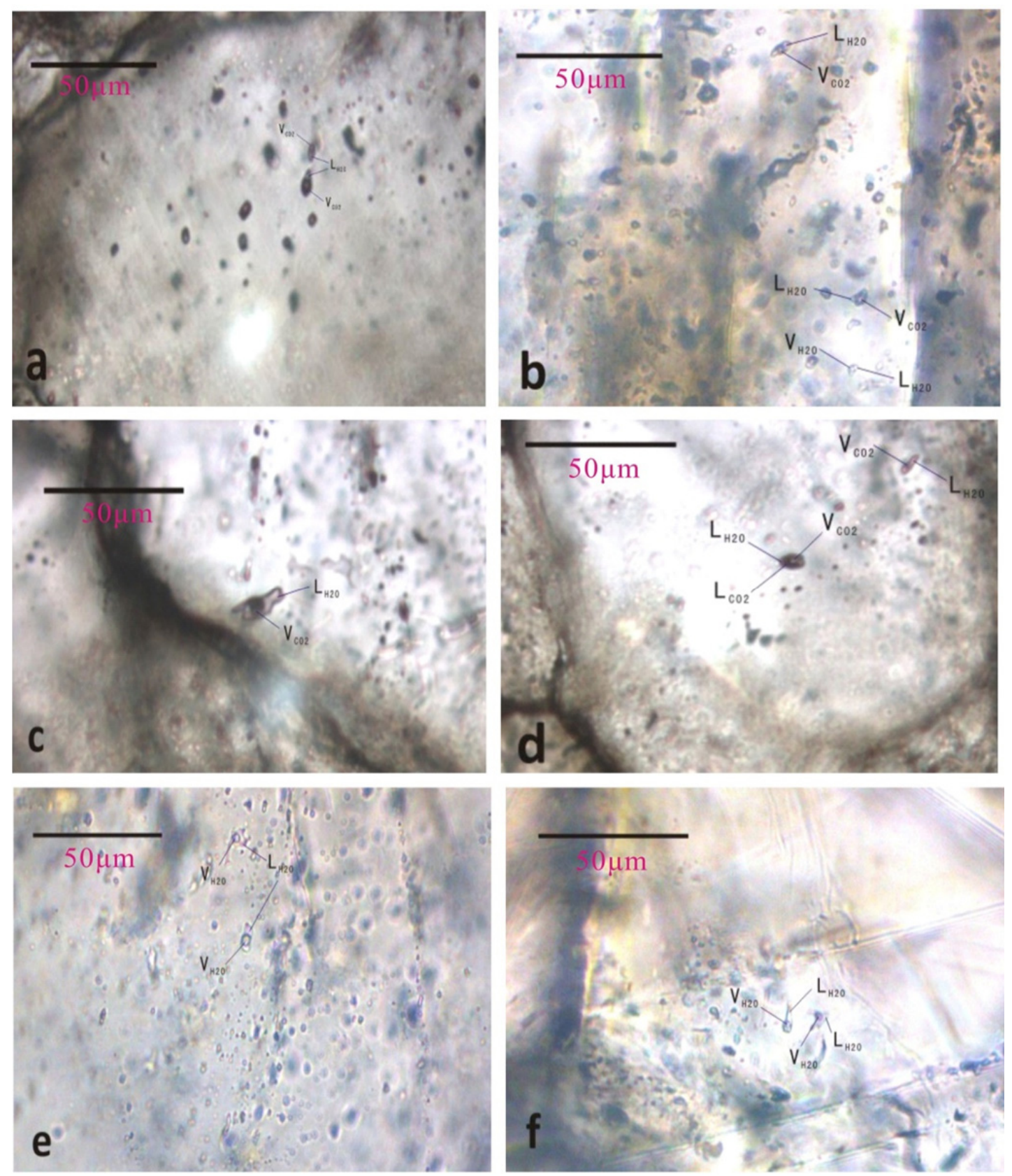

Figure 2. Fluid inclusion micrograph of Jiaojia gold deposit 
Note. a. Lentoid $\mathrm{H}_{2} \mathrm{O}-\mathrm{CO}_{2}$ inclusion is distributed in a scattered mode; b. Strip-type irregular $\mathrm{H}_{2} \mathrm{O}-\mathrm{CO}_{2}$ inclusion and $\mathrm{H}_{2} \mathrm{O}$ solution inclusion; c. Larger $\mathrm{CO}_{2}-\mathrm{H}_{2} \mathrm{O}-\mathrm{CH}_{4}$ inclusion; d. $\mathrm{CO}_{2}-\mathrm{H}_{2} \mathrm{O}-\mathrm{CH}_{4}$ three-phase inclusion and $\mathrm{H}_{2} \mathrm{O}-\mathrm{CO}_{2}$ inclusion; (e, f) . irregular $\mathrm{H}_{2} \mathrm{O}$ solution inclusion.

\subsection{Microscopic Measurement Results}

The fluid inclusion microthermometry analysis is conducted on the Linkan THMS 600 type heating-cooling stage of Chang'an University Metallogeny and Metallogenic Dynamics Key Fluid Inclusion Laboratory of the Ministry of Education, and temperature calibration is conducted on the heating-cooling stage by utilizing the artificially synthesized fluid inclusion standard sample provided by the U.S. FLUIDINC Company. The measurement precision of heating-cooling stage is $\pm 0.5^{\circ} \mathrm{C}$ in the temperature interval of $-120^{\circ} \mathrm{C} \sim-70^{\circ} \mathrm{C}, \pm 0.2^{\circ} \mathrm{C}$ in the interval of $-70 \sim+100^{\circ} \mathrm{C}$ and $\pm 2^{\circ} \mathrm{C}$ in the interval of $100 \sim 500^{\circ} \mathrm{C}$. In the test process of fluid inclusion, the heating rate is generally $5 \sim 10^{\circ} \mathrm{C} / \mathrm{min}$, and it will be reduced to $2^{\circ} \mathrm{C} / \mathrm{min}$ when being close to the phase transformation point temperature so as to accurately record the transformation temperature of phase.

Through the detailed microthermometry on fluid inclusions of the representative sample at all metallogenic stages of Jiaojia Gold deposit and by combining with the inclusion study of predecessors on Jiaojia Gold Mine, it is concluded that the temperature range of main metallogenic epoch is between $170.2 \sim 358.1{ }^{\circ} \mathrm{C}$, the salinity $(\mathrm{NaCl})$ is $2.04 \% \sim 10 \%$ with a mean value of $6.64 \%(\mathrm{NaCl})$.

\subsection{Hydrogen and Oxygen Isotopes Geochemistry}

The former researchers have conducted the hydrogen and oxygen isotope test on the inclusion samples in quartz and pyrite of deposit at different metallogenic stages, and the analysis result is at the Table 1 . The analysis shows that the range of oxygen isotope values of quartz is between $10.4 \% \sim 15.1 \%$, which is lower than that of pyrite $\left(\delta^{18} \mathrm{O}_{\mathrm{V}-\mathrm{S} M O W}=12.04 \% \sim 16.28 \%\right.$ ) , and the hydrogen isotope of quartz is between $\delta \mathrm{D}_{\mathrm{V}-\mathrm{SMOW}}=-32.99 \% \sim-107 \%$, which is higher than that of pyrite $(-83.68 \% \sim-116.96 \%)$.

We projected the hydrogen and oxygen isotopes onto the diagram $\delta^{18} \mathrm{O}-\delta \mathrm{D}$ (Fig. 3), the projection points mainly fall in the range of magmatic water and atmospheric precipitation, and some points fall in the metamorphic water. The hydrogen and oxygen isotopes in the deep and shallow ore body are very similar. Therefore, the comprehensive analysis shows that the metallogenic hydrothermal of Jiaojia Gold Deposit is dominated by the atmospheric precipitation and magmatic water. Moreover, considering the existence of metamorphic water in the metallogenic process and the deep source of metallogenic material, it can be considered that the regional Jiaojia deep fracture plays an important role in the supply of hydrothermal solution during the mineralization.

Table $1 . \delta \mathrm{D}-{ }^{18} \mathrm{O}$ isotope compositions in the Jiaojia gold deposit

\begin{tabular}{lllll}
\hline Measured mineral & $\delta \mathrm{D}_{\mathrm{V}-\mathrm{SMwO}}$ & $\delta \mathrm{O}_{\mathrm{V}-\mathrm{SMwO}}$ & $\delta^{18} \mathrm{D}_{\mathrm{H} 2 \mathrm{O}}$ & Data sources \\
\hline Quartz & -76.6 & 14 & 6.14 & Zhang et al., 2012 \\
Quartz & -70.7 & 13.6 & 5.74 & \\
Quartz & -69 & 15.1 & 7.24 & \\
Quartz & -74.1 & 10.8 & 2.94 & \\
Fluid inclusions in pyrite & -92.76 & 13.24 & 4.95 & Song et al., 2013 \\
Fluid inclusions in pyrite & -116.96 & 16.28 & 5.32 & \\
Fluid inclusions in pyrite & -87.15 & 12.45 & 4.11 & \\
Fluid inclusions in pyrite & -90.16 & 12.88 & 8.35 & \\
Fluid inclusions in pyrite & -83.68 & 12.04 & 5.11 & \\
Fluid inclusions in pyrite & -91.38 & 13.04 & 4.52 & \\
Gold quartz polymetallic sulfide vein & -68.3 & 14.58 & 8.38 & Xin, 2005 \\
Calcite-quartz contains & -107 & 13.7 & 2.8 & \\
While quartz contains & -75.4 & 10.4 & 3.94 & Xu et al., 1997 \\
While quartz contains & -32.99 & 13.74 & 9.69 & \\
\hline
\end{tabular}




\begin{tabular}{lllll}
\hline While quartz contains & -88.9 & 13.55 & 4.59 & \\
While quartz contains & -95.8 & 13.5 & 4.54 & \\
Gold - silver - quartz polymetallic sulfide vein & -75.6 & 13.97 & 5.01 & \\
Ser & -62 & 10.4 & 7.25 & Mao et al.,2008 \\
Ser & -59 & 10.9 & 7.75 & \\
Ser & -59 & 8.4 & 5.25 & \\
K-feld & -86 & 10.2 & 4.37 & \\
K-feld & -85 & 10 & 4.17 & \\
Quartz & -107 & 12.55 & 2.4 & Zhang et al.,1994 \\
Auriferous pyrite & -89 & & -8.5 & Lu et al., 1999 \\
Quartz & -60.1 & & 5.79 & Zhang et al., 1989 \\
Quartz & -60.1 & & 6.69 & Zhang et al., 1993 \\
\hline
\end{tabular}

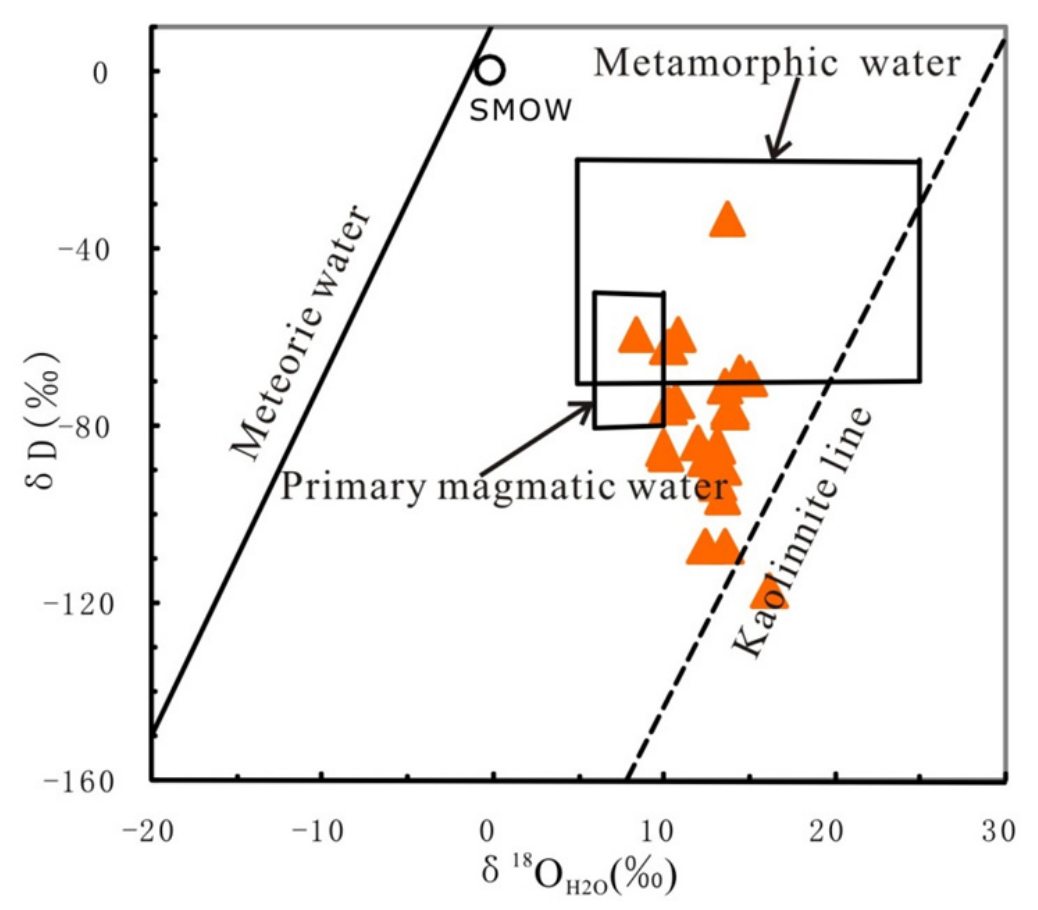

Figure 3. D-O isotopic composition diagrams of fluid inclusions of Jiaojia gold deposit

\subsection{Sulfur Isotopes Geochemistry}

The predecessors have obtained a lot of data of the sulfur isotope, which is shown in Table 2. According to the data in Table 2, we find that the sulfur isotope in the mining area is rich in $\delta^{34} \mathrm{~S} \%$, wherein $\delta^{34} \mathrm{~S}$ is between $6.5 \% \sim 12.72 \%$ with an average value of $10.46 \%$, these values are basically consistent with the $\delta^{34} \mathrm{~S}$ data $(6.5 \%$ $\sim 9.7 \%$, $8.03 \%$ in average; $10.1 \%$ $\sim 12.2 \%$, $11.3 \%$ in average) proposed by Zhang (2012) and Mao et al. (2008), and it belongs to the positive deviation meteorite sulfur. Song et al. (2013) have tested the sulfur isotope of pyrite in Jiaojia deep gold deposit and found that the sulfur isotope of pyrite is relative stable, the variation range is small $\left(\delta^{34} \mathrm{~S}=11.08 \% \sim 12.58 \%\right.$ ), and the sulfur isotope of the deep gold deposit is higher than that of the shallow gold deposit and located at the high value end in the sulfur isotope range $(8.6 \% \sim 11.3 \%$ ) of shallow gold deposit.

Yang et al. (1998) conducted the sulfur isotope test on the main rock unit in the area, wherein the value of $\delta^{34} \mathrm{~S}$ value of Neoproterozoic amphibolites is 5.4\% in average, and the $\delta^{34} \mathrm{~S}$ value of Yanshanian Linglong granite is $8.9 \%$ in average. The sulfur isotope of Jiaojia gold ore is distributed in the sulfur isotope range of surrounding 
granite and Precambrian metamorphic series, but most are located at the high value portion, and it indicates that the source of sulfur in gold deposit is not the pure mantle sulfur or crust sulfur, but belongs to the mixed source. The magma of mantle source is contaminated with the crust substance formed by Precambrian metamorphic rocks and may be mixed with seawater, so formed a mixed sulfur which is rich in $\delta^{34} \mathrm{~S}$.

Table 2. Sulfur isotopic compositions of the Jiaojia gold deposits

\begin{tabular}{|c|c|c|}
\hline Measured mineral & $\delta^{34} \mathrm{~S}(\% 0)$ & Data sources \\
\hline Pyrite & 11.22 & Pang, 2005 \\
\hline Pyrite & 10.99 & \\
\hline Pyrite & 11.06 & \\
\hline Pyrite & 10.75 & \\
\hline Pyrite & 11.53 & \\
\hline Pyrite & 10.92 & \\
\hline Pyrite & 11.27 & \\
\hline Pyrite & 10.79 & \\
\hline Pyrite & 10.85 & \\
\hline Pyrite & 10.59 & \\
\hline Pyrite & 11.01 & \\
\hline Pyrite & 8.3 & Zhang, 2012 \\
\hline Pyrite & 9.7 & \\
\hline Pyrite & 8.4 & \\
\hline Pyrite & 8.8 & \\
\hline Pyrite & 7.9 & \\
\hline Pyrite & 7 & \\
\hline Pyrite & 6.5 & \\
\hline Pyrite & 7.1 & \\
\hline Pyrite & 8.6 & \\
\hline Sulfide & 10.3 & Wang et al., 2001; Wang et al., 1991; Ding et al., 1998; Lin et al., 1999; \\
\hline Pyrite & 12.2 & Mao et al., 2008 \\
\hline Pyrite & 11.4 & \\
\hline Pyrite & 11.5 & \\
\hline Pyrite & 11.3 & \\
\hline Pyrite & 10.1 & \\
\hline Pyrite & 11.12 & Song et al., 2013 \\
\hline Pyrite & 12.58 & \\
\hline Pyrite & 11.46 & \\
\hline Pyrite & 11.08 & \\
\hline Pyrite & 11.23 & \\
\hline Pyrite & 11.4 & \\
\hline Pyrite & 11.36 & \\
\hline Pyrite & 11.18 & \\
\hline Pyrite & 10.65 & M et al.,2015 \\
\hline Pyrite & 11.74 & \\
\hline Pyrite & 11.29 & \\
\hline Pyrite & 8.48 & \\
\hline Pyrite & 8.68 & \\
\hline Pyrite & 10.63 & \\
\hline Pyrite & 12.71 & \\
\hline Pyrite & 8.82 & \\
\hline Pyrite & 11 & \\
\hline Pyrite & 10.26 & \\
\hline Pyrite & 11.82 & \\
\hline Pyrite & 12.72 & \\
\hline Pyrite & 10.47 & \\
\hline Pyrite & 11.16 & \\
\hline
\end{tabular}




\begin{tabular}{lll}
\hline Pyrite & 12.09 & \\
Sulfide & 9.65 & Wang \& Wang, 1991 \\
Pyrite & 10.27 & \\
Pyrite & 10.3 & Wang, 2002 \\
Pyrite & 10.4 & Wang \& Wang, 1991 \\
Pyrite & 10.7 & 6th Geological Brigade of Shandong Province \\
Pyrite & 10.2 & Wang and Third Geological Brigade of Shandong Province \\
Pyrite & 10.27 & Yang et al., 1998 \\
\hline
\end{tabular}

\subsection{Lead Isotope Geochemistry}

There are a lot of data about the characterization study of lead isotope obtained by former researchers (Tab. 3). According to Table 3, the lead isotope composition of Jiaojia Gold Deposit is relatively consistent $\left({ }^{206} \mathrm{~Pb} /{ }^{204} \mathrm{~Pb}=17.117 \sim 17.37,{ }^{207} \mathrm{~Pb} /{ }^{204} \mathrm{~Pb}=15.34 \sim 16.438\right.$ and $\left.{ }^{208} \mathrm{~Pb} /{ }^{204} \mathrm{~Pb}=37.597 \sim 38.072\right)$. When projecting the data result on the ${ }^{207} \mathrm{~Pb} /{ }^{204} \mathrm{~Pb}-{ }^{206} \mathrm{~Pb} /{ }^{204} \mathrm{~Pb}$ tectonic pattern diagram (Fig. 4-a), we
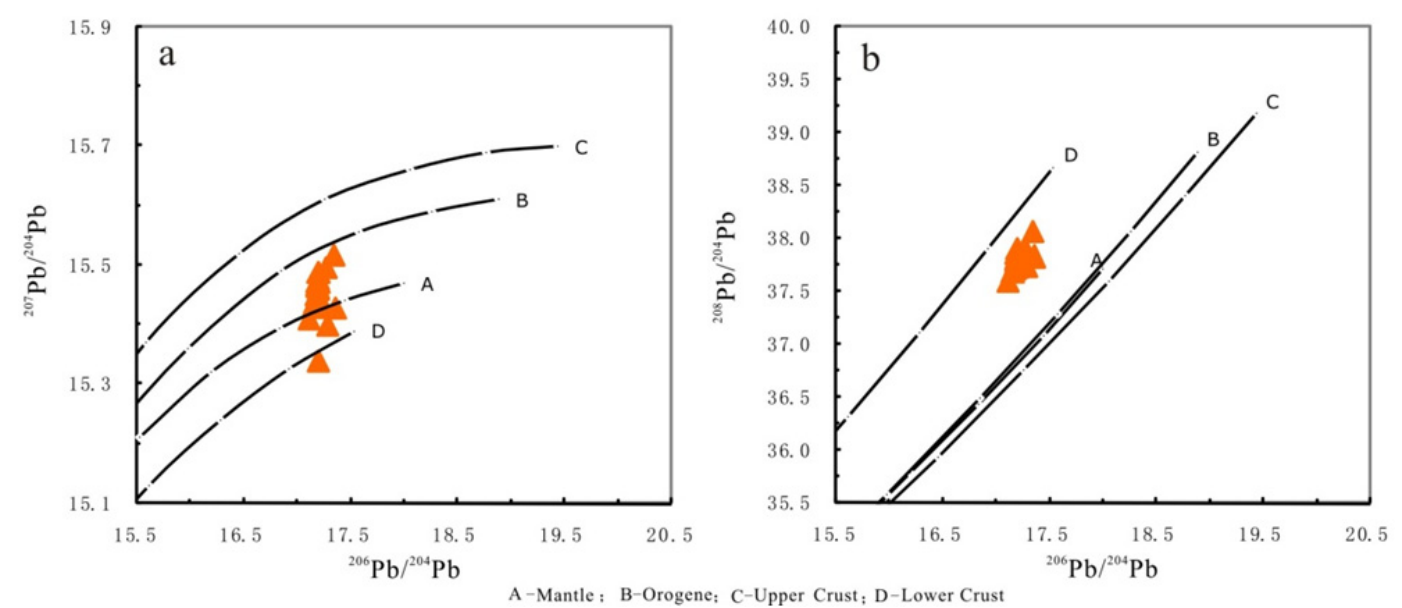

Figure 4. Discrimination diagram of $\mathrm{Pb}$ isotope composition for tectonic settings of Jiaojia gold deposit

can clearly see that the projection points mainly fall between the mantle and orogenic belt, and some points fall between the mantle and lower crust evolving curve; and in the ${ }^{208} \mathrm{~Pb} /{ }^{204} \mathrm{~Pb}-{ }^{206} \mathrm{~Pb} /{ }^{204} \mathrm{~Pb}$ lead isotope tectonic pattern diagram (Fig. 4-b), the lead isotope projection points are very concentrated and fall between the orogenic belt and lower crust evolving curve. The above tectonic figures shows that the metallogenic material is dominated by the crust lead and mixed with mantle lead, and mineralization is formed in the tensional tectonic environment of relatively late period.

Regionally, the ${ }^{206} \mathrm{~Pb} /{ }^{204} \mathrm{~Pb}$ value of two ore-bearing rocks Linglong granite and amphibolites of Jiaojia gold deposit are respectively 17.320 and 17.233 , the ${ }^{207} \mathrm{~Pb} /{ }^{204} \mathrm{~Pb}$ are respectively 15.415 and 15.474 , and the ${ }^{208} \mathrm{~Pb} /{ }^{204} \mathrm{~Pb}$ are respectively 37.752 and 37.356 (Yang et al., 1996). The lead isotope ratio of two rocks is small in difference and shows regular changes, it shows that both rocks have the inheritance relationship on evolution, that is, the Linglong granite is formed by amphibolites under the action of magma remelting. The lead isotope ratio of ore is very close to the value of Precambrian metamorphic series, so it is predicted that the source of metallogenic material is mainly the mixture of ore-bearing granite and Precambrian metamorphic rocks.

Table 3. Lead isotopic compositions of Jiaojia gold deposits

\begin{tabular}{llll}
\hline $\begin{array}{l}\text { Lead isotopic compositions of Jiaojia gold } \\
\text { deposits }\end{array}$ & & \\
${ }^{206} \mathrm{~Pb} /{ }^{204} \mathrm{~Pb}$ & ${ }^{207} \mathrm{~Pb} /{ }^{204} \mathrm{~Pb}$ & ${ }^{208} \mathrm{~Pb} /{ }^{204} \mathrm{~Pb}$ & Data sources \\
17.191 & 15.473 & 37.867 & Yao et al., 1990 \\
17.29 & 15.4 & 37.74 & \\
17.203 & 15.462 & 37.815 & \\
\hline
\end{tabular}




\begin{tabular}{llll}
\hline 17.21 & 15.34 & 37.86 & \\
17.353 & 15.518 & 38.072 & 6th Geological Brigade of Shandong Province \\
17.37 & 15.428 & 37.828 & \\
17.167 & 15.43 & 37.683 & Pang, 2005 \\
17.2 & 15.451 & 37.752 & \\
17.202 & 15.447 & 37.744 & \\
17.212 & 15.489 & 37.908 & \\
17.194 & 15.444 & 37.768 & \\
17.212 & 15.472 & 37.825 & \\
17.194 & 15.45 & 37.751 & \\
17.203 & 15.477 & 37.855 & \\
17.195 & 15.465 & 37.813 & \\
17.191 & 15.467 & 37.796 & \\
17.184 & 15.438 & 37.718 & \\
17.203 & 16.162 & 37.815 & Beijing Institute of Uranium Geology, Minitry of Nuclear \\
& & & Industry, 1983 \\
17.21 & 15.34 & 37.89 & Institute of Geochemistry, Chinese Academy of Sciences, 1981 \\
17.37 & 16.438 & 37.828 & Institute of Geochemistry, Chinese Academy of Sciences, 1987 \\
17.25 & 15.43 & 37.82 & Wang et al., 2001; Wang et al., 1991; Ding et al., 1998;Lin et \\
& & & al., 1999; Wen et al., 1990;Yao et al., 1990 \\
17.203 & 15.46 & 37.815 & Yao et al., 1983 \\
15.21 & 15.34 & 37.89 & Shenyang Institute of Geology and Mineral Resources \\
17.198 & 15.438 & 37.742 & Ding et al., 1998 \\
17.207 & 15.444 & 37.727 & \\
17.117 & 15.41 & 37.597 & \\
17.278 & 15.497 & 37.909 & \\
\hline
\end{tabular}

\section{Mineralogenetic Epoch}

For the mineralogenetic epoch and granite study in Jiaodong area, the predecessors have accumulated a lot of data (As shown in Fig. 5), including the granite petrology and geochemistry (Li et al., 1986; Sang et al., 1984, 1992; Wang et al., 1985, 1986, 1988; Qiu et al., 1988; Wang et al., 1988; Xu et al., 1989; Yao et al., 1990; Li et al., 1993; Yang et al., 1996), granite factor (Qiu et al., 1988; Xu et al., 1989; Lv et al., 1993; Chen et al., 1993; Luo et al., 2002; Zhao et al., 2003), granite chronology (Luo et al., 2002) and granite genetic mineralogy (Chen et al., 1993). The Mesozoic granite distribution range in Jiaodong area is relatively broad, such as the "Linglong" biotite granite or gneissic granite in west of Jiaodong and the "Guajialing" maculosus granodiorite. Moreover, Kunyu Mountain- Que Mountain granite and granitic rock mass of Jiazi Mountain, Cha Mountain and Weide Mountain are developed in the east of Jiaodong (Guo, 2009). For the granite, the Linglong- Kunyu Mountain gneissic (biotite) monzonitic granite with the diagenesis age of 160-150Ma, the Guojialing maculosus granodiorite with the emplacement age of 130-126Ma and the Luanjia River-Weide Mountain coarse grain monzonitic granite with the age range of $127-105 \mathrm{Ma}$ have close relationship with Jiaodong gold mineralization (Lv, 2011). After long magma activity period of Mesozoic, the famous Jiaodong gold metallogenic epoch occurs, wherein the Mesozoic granite has a great relationship with Jiaodong gold mineralization, especially the Weide Mountain granite, it plays a crucial role in mineralization (Song et al., 2010). There are different opinions about the metallogenic epoch of Jiaodong Gold, for example, some scholars think that the metallogenic epoch is about 115 $\pm 15 \mathrm{Ma}$ (Liu, 2001; Guo, 2009), 122.7 121.7Ma belongs to the Middle Yanshanian (Li, 1993) and 121.3-113.5Ma belongs to the Late Yanshanian (Song, 2011). Moreover, some scholars think that the Jiaodong area has two gold ores such as the gold ore of about 120-100Ma and the gold-silver-polymetallic ore of 80-90Ma (Yang, 2006), and the metallogenic age is mainly distributed in 120Ma. Due to the natural environment, the Sanshan Island gold ore and the Jiaojia gold ore field have the special and irreplaceable metallogenic geological environment (Li, 2013). 

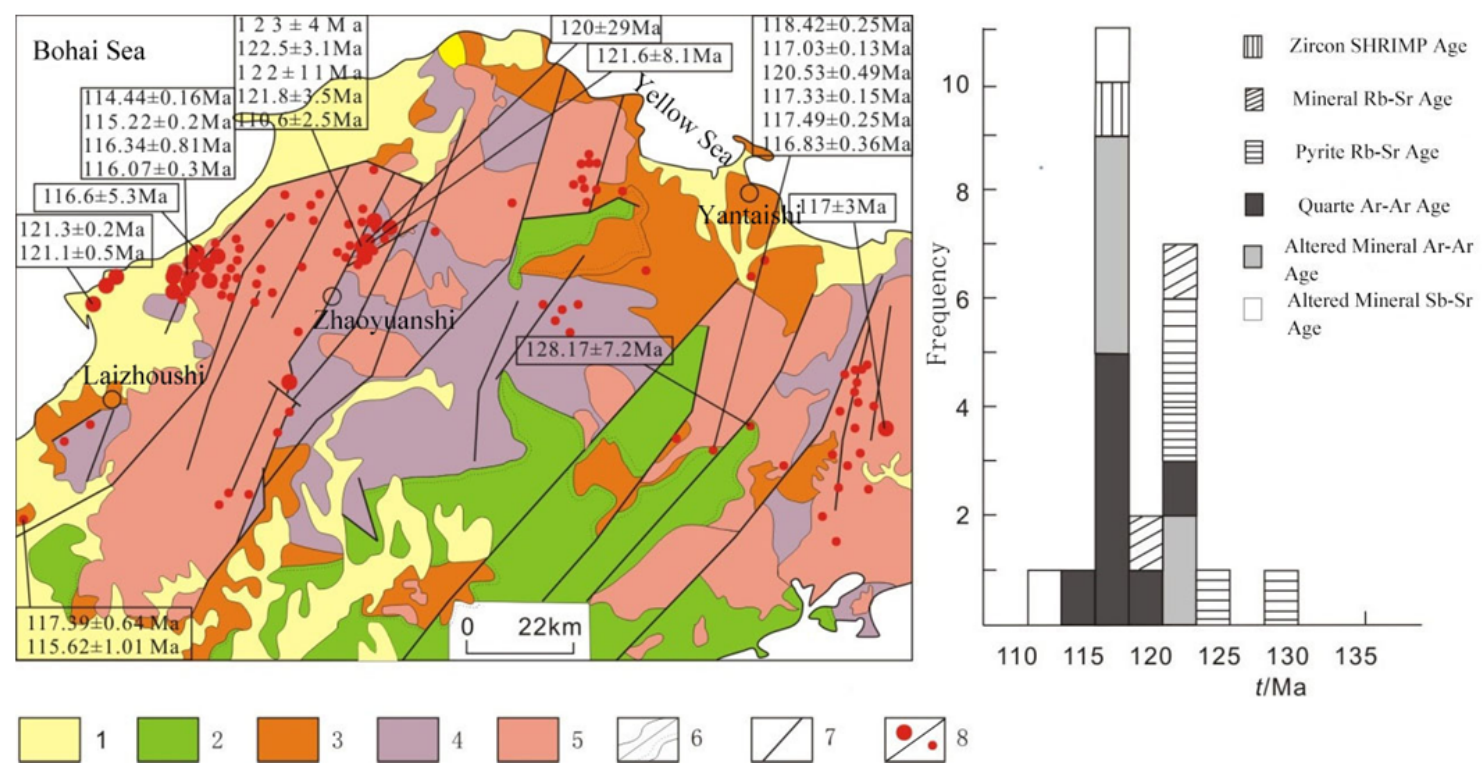

Figure 5. Spatial distribution and temporal histogram of gold deposition in the Jiaodong Peninsula (modified after Song et al., 2015)

Note. 1. Neogene+Paleogene; 2. Cretaceous; 3. Palenproterozoic and Neoproterozoic; 4. Precambrian granitic gneiss; 5. Jurassic-Cretaceous granite; 6. Conformable/unconformable geological boundary; 7. Fault; 8 . Large-superlarge gold deposit/minor gold deposit.

\section{Metallogenic Model}

In the early and middle of Mesozoic, the paleo-pacific plate drove to the eurasian plate rapidly from the SE direction to the NW inclined direction. Jiaodong area is at the collision orogeny stage and generates a series of conjugated brittle-ductile fracture systems (Fractures such as Sanshan Island, Jiaojia- Xincheng and Zhaoping) and the steep dip brittle fracture systems in the NNE direction in the northwest of Jiaodong peninsula. At the relaxation stage during collision orogeny, a lot of granite magma was generated through the syntactic or remelting function and intrusion emplacement occurs, and most granite rocks were formed at the footwall of brittle-ductile fracture. Formed in the Proterozoic era and parallel to the Qixia anticlinorium, the archaic fracture structure with the EW direction also generated the inheritance activities in this period. These fractures together with the brittle-ductile fault control the formation and distribution of the granite and gold deposit of this area.

In late Mesozoic, it is a crucial period of transition of dynamics system in Eastern Shandong since the Middle Jurassic, namely the conversion system of the collision to extension in late Mesozoic, which is characterized by readjustment of tectonic structure after subduction or the transition period of backward arc extensional dynamics environment. The Earth's surface is formed depression after extension and detachment, the upheaval of upper mantle prompts lithospheric delamination thinning, deep faults generated or activated, and undercut Tanlu fracture with strong sinistral strike-slip. This period is also the most intense period of the lithospheric thinning in eastern China, mainly intra-continental extension and lithospheric thinning, and there is mantle upwelling. With deep faults cutting into the upper mantle, strong upwelling of deep thermal and young asthenosphere material, accompanied by a large-scale and mixed crust-mantle material, with the mantle magma intrusion, geothermal gradient continues to grow, and further generates a lot of heat, resulting in lower crust or the crust-mantle re-melting with molten magma produced massive invasion activities and formation of metallogenic fluids, which leads to continuous consumption of lithospheric mantle and thinning. It results in a strong upwelling of deep mantle materials and energy; the upper mantle ore elements ( $\mathrm{Au}, \mathrm{Te}, \mathrm{Cu}$, etc.) were taken out ( $\mathrm{Au}, \mathrm{Te}, \mathrm{Cu}$, etc.). These elements move upward through the multi-stage evolution of mantle plume, leading to a large-scale, long-range migration. Ore-forming fluids continuously extract the minerals in the surrounding rock during the rising process. Due to the tectonic nature (toughness $\rightarrow$ brittle-ductile $\rightarrow$ brittle) and the transition of the physical and chemical conditions of ore containing fluid, immiscible fluids become immiscible and phase-separated, resulting in a fracture or toughness shear zone mineralization superimposed parts gathered, forming a large number of hydrothermal lode gold deposits. 


\section{Conclusions}

The study of fluid inclusions determined that the Jiaojia gold Deposit is a medium-temperature deposits; metallogenic fluid is $\mathrm{CO}_{2}-\mathrm{H}_{2} \mathrm{O}-\mathrm{NaCl}\left( \pm \mathrm{CH}_{4}\right)$ system; the main metallogenic temperature is $170.2 \sim 358.1^{\circ} \mathrm{C}$, salinity $(\mathrm{NaCl})$ is $2.04 \% \sim 10 \%$; the average salinity $(\mathrm{NaCl})$ is $6.64 \%$; an overall density is $0.89 \sim 0.946 \mathrm{~g} /$ $\mathrm{cm}^{3}$, and the pressure estimate is $2 \times 10^{3} \sim 3.8 \times 10^{3} \mathrm{kPa}$.

The analysis and research on hydrogen and oxygen isotopes in Jiaojia Gold Deposit show that the hydrogen and oxygen isotopes from deep and shallow ore body are very similar. Ore-forming hydrothermal solution of Jiaojia Gold Deposit is derived from meteoric and magmatic water, a small part of metamorphic water also involved in the ore-forming process, indicating that the mineralization is a long process with inheritance. Combined with deep source of metallogenic material, Jiaojia fault has a major role in the gold mineralization structurally, which is regional, vertical and deep in spacial. In the process of mineralization, the regional tectonic - Jiaojia fracture has critical impact on the meteoric water.

The study of sulfur and lead isotopes of Jiaojia Gold Deposit shows the sulfur of Jiaojia Gold Deposit is not simply from mantle or crust, but is mixed sulfur. Mantle-derived magma mixed by crustal material formed by Precambrian metamorphic rocks, and may be mixed with seawater, forming mixed sulfur rich in $\delta^{34} \mathrm{~S}$. The main source of lead derived from crust, and mixed with the mantle lead, mineralization formed in a relatively late extensional background. The ratio of lead isotope of ore and granite in surrounding rock is very close to Precambrian metamorphic rocks series, so we presume that the source rocks of mineralization are mainly ore-bearing granitoids and Precambrian metamorphic rocks.

\section{References}

Yao, F. L., Liu, L. D., Kong, Q. C., \& Gong, R. T. (1983). The stability isotopic geology and the origin of the gold deposit in the Zhaoyuan-Yexian gold belt, Shangdong province. Journal of Changchun University of Earth Sciences, (4), 7-18.

Xu, J. H., Xie, Y. L., \& Shen, S. L. (1997). A comparison of ore-forming fluids between gold deposit in Xiaoqinling Mountains and those in Jiaodong peninsula. Mineral Deposits, 16(2), 151-162. Retrieved from http://dx.doi.org/10.16111/j.0258-7106.1997.02.006

Zhang, L. C., Shen, Y. C., Zeng, Q. D., \& Zou, W. L. (2001). Sulfur and lead isotopic geochemistry of gold deposits at the Northern Margin of Jiaolai Basin, East Shandong. Bulletin of Mineralogy, Petrology and Geochemistry, 20(4), 380-384. Retrieved from http://dx.doi.org/10.3969/j.issn.1007-2802.2001.04.049

Zhang, J. N. (2012). Mineralization enrichment regularity and the genesis discussed of Jiaojia gold deposit, Shangdong province Laizhou. Master Thesis Jilin University, 1-72.

Pang, X. C. (2005). Geochemistry and deep ore prediction of the Jiaojia gold deposit, Shangdong. Doctor Thesis Chengdu University of Technology, 1-133.

Wang, H. N., \& Wang, Y. (1991). The genesis of the Jiaojia gold deposit, Shangdong. Geological Review, 37(3), 250-258. Retrieved from http://dx.doi.org/10.16509/j.georeview.1991.03.007

Li, H. K., Shi, W. G., Li, Y. F., Li, L. Y., Han, D. C., Cao, L. L., \& Liu, J. (2013). M. Study on gold mineralization ages in Jiaodong area, Shangdong province. Gold Science and Technology, 21(3), 1-9. Retrieved from http://dx.doi.org/10.3969/j.issn.1005-2518.2013.03.001

Lu, H. Z., Yuan, W. C., Zhang, G. P., Li, Y, S., \& Long, H. B. (1999). Stable isotopes studies and age dating of gold deposit and linglong granites in Linglong-Jiaojia area, Shandong, China. Journal of Guilin Institute of Technology, 19(1), 1-8. Retrieved from http://dx.doi.org/10.3969/j.issn.1674-9057.1999.01.001

Wang, Z. L. (2012). Metallogenic system of Jiaojia gold orefield, Shandong province, China. Doctor Thesis China University of Geosciences, 1-208.

Luo, Z. K., Guan, K., Yu, H. Y., \& Li, Y. M. (2003). The key factors for formation of large-superlarge Au deposit in Zhaolai area, Jiaodong region. Contributions to Geology and Mineral Resources Research, 18(2), 95-102.

Xin, H. B. (2005). The contrast of geological feature and genesis between Xiejiagou gold deposit and Jiaojia gold deposit in Jiaodong area. Master Thesis China University of Geosciences, 1-114.

Mao, J. W., He, Y., \& Ding, T. P. (2002). Mantle fluids involved in metallogenesis of Jiaodong (East Shandong) gold district: Evidence of $\mathrm{C}, \mathrm{O}$ and $\mathrm{H}$ isotopes. Mineral Deposits, 21(2), 121-128. Retrieved from http://dx.doi.org/10.16111/j.0258-7106.2002.02.004 
Lin, W. W., Zhao, Y. M., \& Zhao, G. H. (1999). The characteristics of Lead isotope of Jiaodong area and discussion of minerogenetic epoch. Journal of Changchun University of Science and Technology, 29(2), 116-121. Retrieved from http://dx.doi.org/10.13278/j.cnki.jjuese.1999.02.004

Lv, C. X. (2012). The study of geologic characteristics of regional tectonic altered rock belt and regulation of fluid mineralization in Jiaodong peninsula. Master Thesis China University of Geosciences for Master Degree, 1-74.

Song, M. C., Cui, S. X., Zhou, M. L., Jiang, H. L., Yuan, W. H., Wei, X. F., \& Lv, G. X. (2010). The deep oversize gold deposit in the Jiaojia field, Shandong Province and its enlightenment for the Jiaojia-type gold deposits. Acta Geological Sinsca, 84(9), 1349-1358.

Song, M. C., Song, Y. X., Shen, K., Jiang, H. L., \& Li, S. Y. (2013). Geochemical features of deeply-seated gold deposit snd discussions on some associated problems in Jiaojia gold ore field, Shandong peninsula, China. Geochimica, 42(3), 274-289. Retrieved from http://dx.doi.org/10.3969/j.issn.0379-1726.2013.03.008

Wang, Y. W., Zhu, F. S., \& Gong, R. T. (2002). Tectonic isotope geochemistry-Further study on sulphur isotope of Jiaodong gold concentration area. Gold, 23(4), 1-16. Retrieved from http://dx.doi.org/10.3969/j.issn.1001-1277.2002.04.001

Mao, J. W., Wang, Y. T., \& Li, H. M. (2008). The relationship of mantle-derived fluids to gold metallogenesis in the Jiaodong Peninsula: Evidence from D-O-C-S isotope systematic. Ore Geology Reviews, 33, 361-381. Retrieved from http://dx.doi.org/ 10.1016/j.oregeorev.2007.01.003

Li, L., Santosh, M., \& Li, S. R. (2015). The 'Jiaodong type' gold deposits: Characteristics, origin and prospecting. Ore Geology Reviews, 65, 589-611. Retrieved from http://dx.doi.org/10.1016/j.oregeorev.2014.06.021

Li, S. R., \& Santosh, M. (2014). Metallogeny and craton destruction: Records from the North China Craton. Ore Geology Reviews, 56, 376-414. Retrieved from http://dx.doi.org/10.1016/j.oregeorev.2013.03.002

Mills, S. E., Tomkins, A. G., \& Weinberg, R. B. (2015). Anomalously silver-rich vein-hosted mineralisation in disseminated-style gold deposits, Jiaodong gold district, China. Ore Geology Reviews, 68, 127-141. Retrieved from http://dx.doi.org/10.1016/j.oregeorev.2014.12.014

Yan, Y. T., Zhang, N., \& Li, S. R. (2014). Mineral chemistry and isotope geochemistry of pyrite from the Heilangou gold deposit, Jiaodong Peninsula, Eastern China. Geoscience Rontiers, 5, 205-213. Retrieved from http://dx.doi.org/10.1016/j.gsf.2013.05.003

\section{Copyrights}

Copyright for this article is retained by the author(s), with first publication rights granted to the journal.

This is an open-access article distributed under the terms and conditions of the Creative Commons Attribution license (http://creativecommons.org/licenses/by/4.0/). 